\title{
Economic Feasibility of Anaerobic Digestion To Produce Electricity on Florida Dairy Farms ${ }^{1}$
}

\author{
Russ Giesy, Ann C. Wilkie, Albert de Vries, Roger A. Nordstedt ${ }^{2}$
}

\section{Introduction}

There are four different digester designs currently used in the U.S. for anaerobic digestion of dairy manure: 1) covered lagoon, 2) fixed film, 3) complete mix, and 4) plug flow.

Covered lagoons are impoundments with a gas-tight cover installed to capture the biogas. This design typically handles a solids content of $<2 \%$ and operates at ambient temperatures. Hydraulic retention times (HRT) vary from 35 days in the south to 60 days in more northerly regions. Biogas production tends to vary seasonally due to temperature fluctuations. Fibrous solids are removed prior to digestion. The covered lagoon digester is suitable for flushed manure operations typically found on Florida dairy farms.

The fixed-film digester immobilizes bacteria on a packing material, or media, within the reactor vessel, thereby preventing washout of microbial biomass. This design typically handles a solids content of < $2 \%$ and can operate at ambient or higher temperatures. At ambient temperature, the lower rate of metabolism is offset by a high microbial mass.
HRT is in the order of 2-4 days. Fibrous solids are removed prior to digestion. Higher levels of solids can be tolerated, depending on biodegradability. Also, the fixed-film design can tolerate the presence of some fine sand grains in the flushed manure with no change in performance. The fixed-film digester is suitable for flushed manure operations typically found on Florida dairy farms.

Complete-mix digesters, also called continuously stirred tank reactors, are systems where the digester contents are mixed by mechanical agitation, effluent recirculation, or biogas recirculation. Despite the name, mixing tends to be intermittent rather than continuous. Digester tanks have been constructed of coated steel or concrete. This design typically handles a solids content of $3-10 \%$ and operates at mesophilic temperature $\left(35^{\circ} \mathrm{C}, 95^{\circ} \mathrm{F}\right)$. HRTs vary from 20 to 25 days. The solids content in flushed manure from Florida dairy farms is typically too low to make complete-mix digesters feasible.

\section{Plug-flow digesters are unmixed systems in} which undiluted manure flows semi-continuously as a plug through a horizontal reactor. The reactor is usually an intank, with either a fixed or a flexible

1. This document is AN159, one of a series of the Animal Science Department, Florida Cooperative Extension Service, Institute of Food and Agricultural Sciences, University of Florida. Original publication date November 2005. Visit the EDIS Web Site at http://edis.ifas.ufl.edu.

2. Russ Giesy, Multi-County Dairy Agent IV, Sumter County; Ann C. Wilkie, Courtesy Associate Professor, Soil and Water Science; Albert de Vries, Assistant Professor, Department of Animal Sciences; Roger A. Nordstedt, Professor, Agricultural \& Biological Engineering; Florida Cooperative Extension Service, Institute of Food and Agricultural Sciences, University of Florida, Gainesville, FL, 32611. 
cover. This design typically handles a solids content of $10-14 \%$ and operates at mesophilic temperature. HRTs vary from 20 to 30 days. The plug-flow digester is suitable for scraped manure operations. The solids content in flushed manure from Florida dairy farms is typically too low to make plug-flow digesters feasible.

Because complete-mix digesters and plug-flow digesters are not feasible for the flushed manure systems typically found on Florida dairy farms, only the economic feasibilities of covered lagoons and fixed-film digesters were evaluated. This paper focuses on the economic feasibilities of using these digester designs to generate electricity for on-farm use or sales.
As directed by FDACS, the consultants used the following assumptions in their analyses:

1. The amount of water used was 200 gallons per cow per day.

2. The efficiency of generation of electricity from biogas was $25 \%$.

3. All wastewater would be anaerobically digested prior to use as recycled flush water.

Estimates of potential biogas and electricity production on the three farms were similar from both consulting firms. Investment costs and operating and maintenance costs provided by these firms were

Table 1. Key design data for the three dairy farms.

\begin{tabular}{lccc}
\hline & Farm A & Farm B & Farm C \\
\hline Number of cows & 650 & 2100 & 600 \\
$\mathrm{CH}_{4}$ produced (ft ${ }^{3}$ day) & 38,984 & 83,966 & 39,984 \\
$\mathrm{CO}_{2}$ produced (tons/year) & 6,331 & 13,636 & 6,493 \\
Electricity consumed (kWh/year) & $1,125,840$ & $2,414,753$ & 405,114 \\
Electricity produced (kWh/year) & $1,042,593$ & $2,245,584$ & $1,069,326$ \\
Electricity produced/consumed (\%) & $93 \%$ & $93 \%$ & $264 \%$ \\
Hydraulic retention time (days) & & & 3 \\
$\quad$ Fixed film & 3 & 3 & 38 \\
$\quad$ Covered lagoon & 35 & 10 & 10 \\
Life of investment (years) & 10 & & 38 \\
\hline
\end{tabular}

\section{Methods and Approach}

A grant from the Florida Department of Agriculture and Consumer Services (FDACS) was used to employ the services of two consulting firms that were familiar with the design and operation of fixed-film and covered lagoon digesters. The consultants visited three dairy farms located in Florida in the winter of 2005, calculated wastewater flows (including flushed manure, milking parlor wastewater, and recycled flush water), and determined the size and other necessary aspects of the potential systems specific to each dairy farm.

Estimates were developed for the quantities of biogas and electricity that would be generated by each system. The consulting firms also projected initial capital investment costs and operating and maintenance costs for each system. reconciled. Therefore, one set of input values was used for each dairy farm.

Default assumptions were as follows: 1) discount rate was $8 \%$ per year, 2) owner's share of the investment was $100 \%, 3$ ) retail value of electricity was assumed to be $\$ 0.10$ per $\mathrm{kWh}, 4$ ) wholesale price of electricity was assumed to be $\$ 0.035$ per $\mathrm{kWh}, 5$ ) milk production per cow was $15,000 \mathrm{lbs} /$ year, 6 ) the digesters were designed to process all the wastewater that was produced on the farms, and 7) salvage value after 10 years was $\$ 0$.

Sensitivity analyses were conducted to assess the feasibility of the investments for different owner's share of capital investment costs, discount rates, and retail values of electricity. The net present value (NPV) of each digester investment was calculated. NPV is the sum of expected net cash flows, measured 
in today's dollars. Higher NPV values represent greater economic benefit. A NPV greater than $\$ 0$ indicates that the digester design is more profitable than the next best alternative (which generates $8 \%$ return on investment per year) and, therefore, the preferable investment.
The capital cost for electricity generation ranged from slightly less than $\$ 0.5$ million to $\$ 1.1$ million. Per cow the range was $\$ 452$ to $\$ 1,173$. Expressed over ten years, total capital costs (interest and depreciation) ranged from $\$ 0.30$ to $\$ 0.78$ per cwt of milk. Some of the differences in capital costs could

Table 2. Capital costs and operating and maintenance cost for electricity generation at three Florida dairy farms.

\begin{tabular}{|c|c|c|c|c|c|c|}
\hline & \multicolumn{2}{|c|}{ Farm A } & \multicolumn{2}{|c|}{ Farm B } & \multicolumn{2}{|c|}{ Farm C } \\
\hline & $\begin{array}{l}\text { Fixed } \\
\text { Film }\end{array}$ & $\begin{array}{l}\text { Covered } \\
\text { Lagoon }\end{array}$ & $\begin{array}{l}\text { Fixed } \\
\text { Film }\end{array}$ & $\begin{array}{l}\text { Covered } \\
\text { Lagoon }\end{array}$ & $\begin{array}{l}\text { Fixed } \\
\text { Film }\end{array}$ & $\begin{array}{c}\text { Covered } \\
\text { Lagoon }\end{array}$ \\
\hline Number of cows & 650 & 650 & 2100 & 2100 & 600 & 600 \\
\hline Capital cost & $\$ 762,456$ & $\$ 479,491$ & $\$ 1,144,182$ & $\$ 949,478$ & $\$ 627,459$ & $\$ 530,284$ \\
\hline Capital cost/cow & $\$ 1,173$ & $\$ 738$ & $\$ 545$ & $\$ 452$ & $\$ 1,046$ & $\$ 884$ \\
\hline Capital cost/cwt of milk & $\$ 0.78$ & $\$ 0.49$ & $\$ 0.36$ & $\$ 0.30$ & $\$ 0.70$ & $\$ 0.59$ \\
\hline $\mathrm{O}+\mathrm{M}$ cost/cwt of milk & $\$ 0.16$ & $\$ 0.10$ & $\$ 0.07$ & $\$ 0.06$ & $\$ 0.14$ & $\$ 0.12$ \\
\hline
\end{tabular}

\section{Results and Discussion}

\section{Design Results}

Electricity consumption and production and biogas production for the three dairy farms is shown in Table 1. Production of methane $\left(\mathrm{CH}_{4}\right)$ and electricity were estimated to be the same for the fixed-film digester and the covered lagoon.

Farms A and B would generate almost enough electricity to supply their entire demand. At the time of data collection, Farm $\mathrm{C}$ was transitioning from rotational grazing to freestall barns. Rotational grazing uses less electricity per cow than freestall barns. Therefore, the electricity consumed on this farm does not reflect the expected consumption when the cows are housed in the freestall barns. Since all digesters were designed for cows in freestall barns, the excess electricity production for Farm $\mathrm{C}$ is an anomaly. This means that NPV calculations for Farm $\mathrm{C}$ are not reliable, particularly since the sale price for excess electricity is lower than the retail cost. Farm C was excluded from consideration, therefore, in the sensitivity analyses.

\section{Capital Investment}

Estimated capital investment and operation and maintenance $(\mathrm{O}+\mathrm{M})$ costs required for the digesters at the three dairy farms to generate electricity are shown in Table 2. Annual operation and maintenance costs were assumed to be $2 \%$ of capital cost. be attributed to differences in existing infrastructure between the three dairy farms. Economies of scale were evident from a comparison of the projected costs for Farm B to those for Farm A and Farm C. Operation and maintenance costs were estimated to range from $\$ 0.06$ to $\$ 0.16$ per cwt of milk. Capital costs were higher for fixed-film digesters.

Biogas systems required about $20 \%$ less initial capital expenditure than systems that included biogas to electricity conversion. Sale of biogas produced at the farm level is currently limited by the lack of infrastructure to transport the biogas to consumers. Also, the sale of biogas for uses other than generation of electricity would require further clean up and additional costs. Therefore, the feasibility of biogas sales was not further considered. However, this may be a viable option for a limited number of farms if a gas consumer is located within a short distance from the farm.

\section{Owner's Share of Capital Investment}

The costs of the investment in digesters would be affected by opportunities for cost share that exist for some dairy farms. The level of cost share available was expected to greatly affect the feasibility of the designs. Table 3 shows results of NPV calculations for Farms A and B with different owner's share, while other factors remained at their default values. These results are presented graphically in Figure 1. 


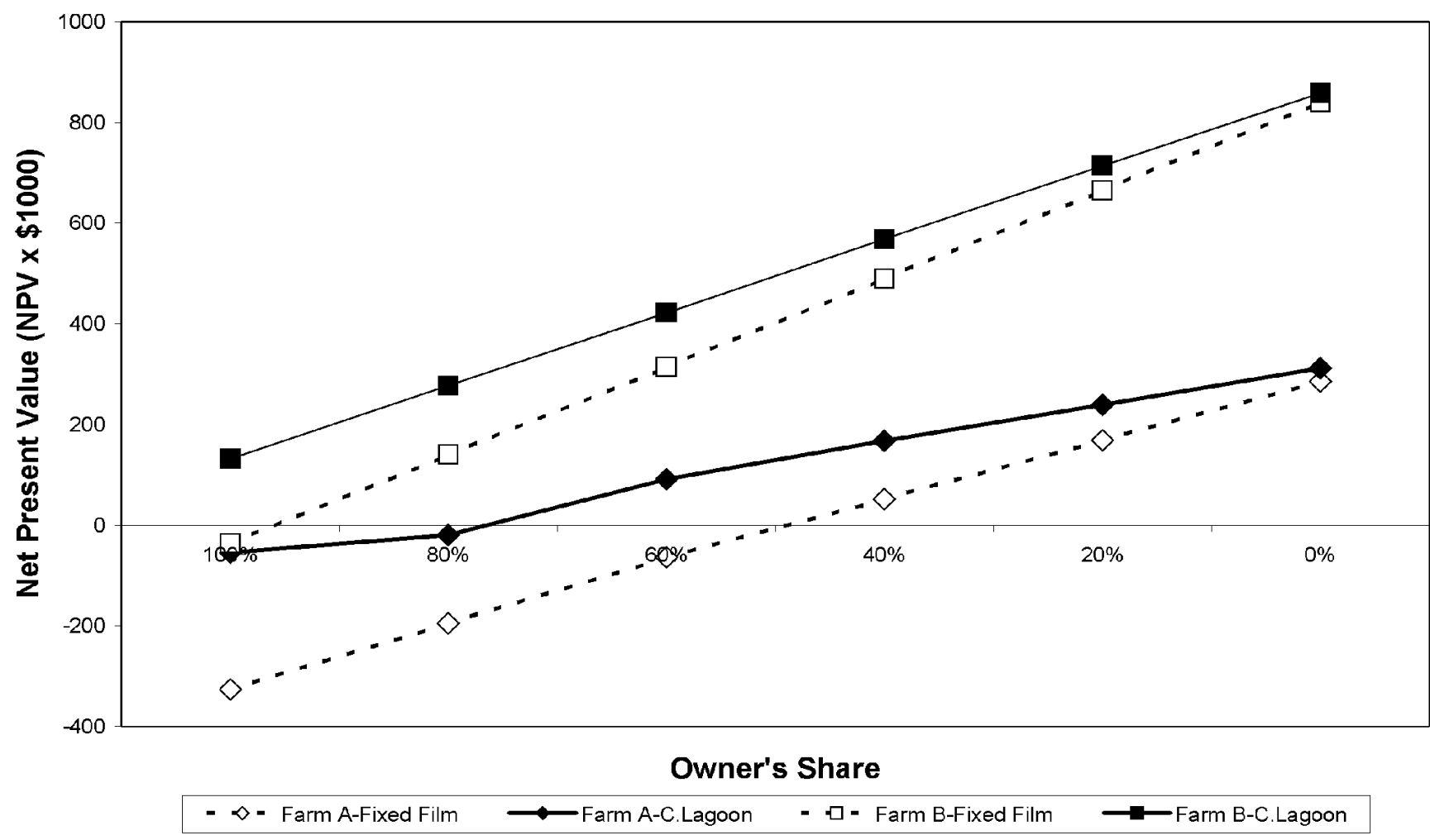

Figure 1. Effect of owner's share on the capital investment cost for electricity generation.

These results showed that a covered lagoon may be profitable at 100\% owner's share for Farm B, while the fixed-film digester is profitable for Farm B at $95 \%$ owner's share. Meanwhile, at Farm A, the breakeven owner's share of a covered lagoon was about $75 \%$ compared to approximately $50 \%$ for a fixed-film digester. Farm A would need to obtain significant cost-share funds to make digesters economically feasible on this farm.

\section{Discount Rates}

The discount rate is the opportunity cost of capital. It includes the interest rate if the money for the investment needs to be borrowed. Table 4 shows results of NPV calculations for Farms A and B with different discount rates from $0 \%$ to $10 \%$, while other factors remained constant. Owner's share of the capital cost was assumed to be $100 \%$. These results are presented graphically in Figure 2.

Discount rate had an effect on the potential investment. At Farm B, a covered lagoon seemed feasible at $10 \%$ and a fixed-film digester may be profitable at about $7 \%$ or less. Meanwhile, at Farm A, the fixed-film investment was below zero, even at
$0 \%$, while the breakeven discount rate of a covered lagoon was about $3.5 \%$.

\section{Value of Electricity}

The electricity generated from the biogas was assumed to be used on the farm, thus foregoing the need to purchase electricity at the retail price. Therefore, the retail value of electricity affected the feasibility of the additional investment required in systems to generate electricity from biogas. Table 5 shows results of NPV calculations for Farms A and B with differing retail values from $\$ 0.04$ to $\$ 0.16$ per $\mathrm{kWh}$, while other factors remained constant. These results are presented graphically in Figure 3.

In general, the retail value of electricity would have to remain above $\$ 0.12$ per $\mathrm{kWh}$ to make digesters feasible in most scenarios. For Farm B, breakeven was reached for the covered lagoon and fixed-film digester at about $\$ 0.085$ and $\$ 0.105$ per $\mathrm{kWh}$, respectively. For Farm A, the covered lagoon had a breakeven value of approximately $\$ 0.115$, while the fixed-film digester required almost $\$ 0.16$ per $\mathrm{kWh}$ to be feasible. 


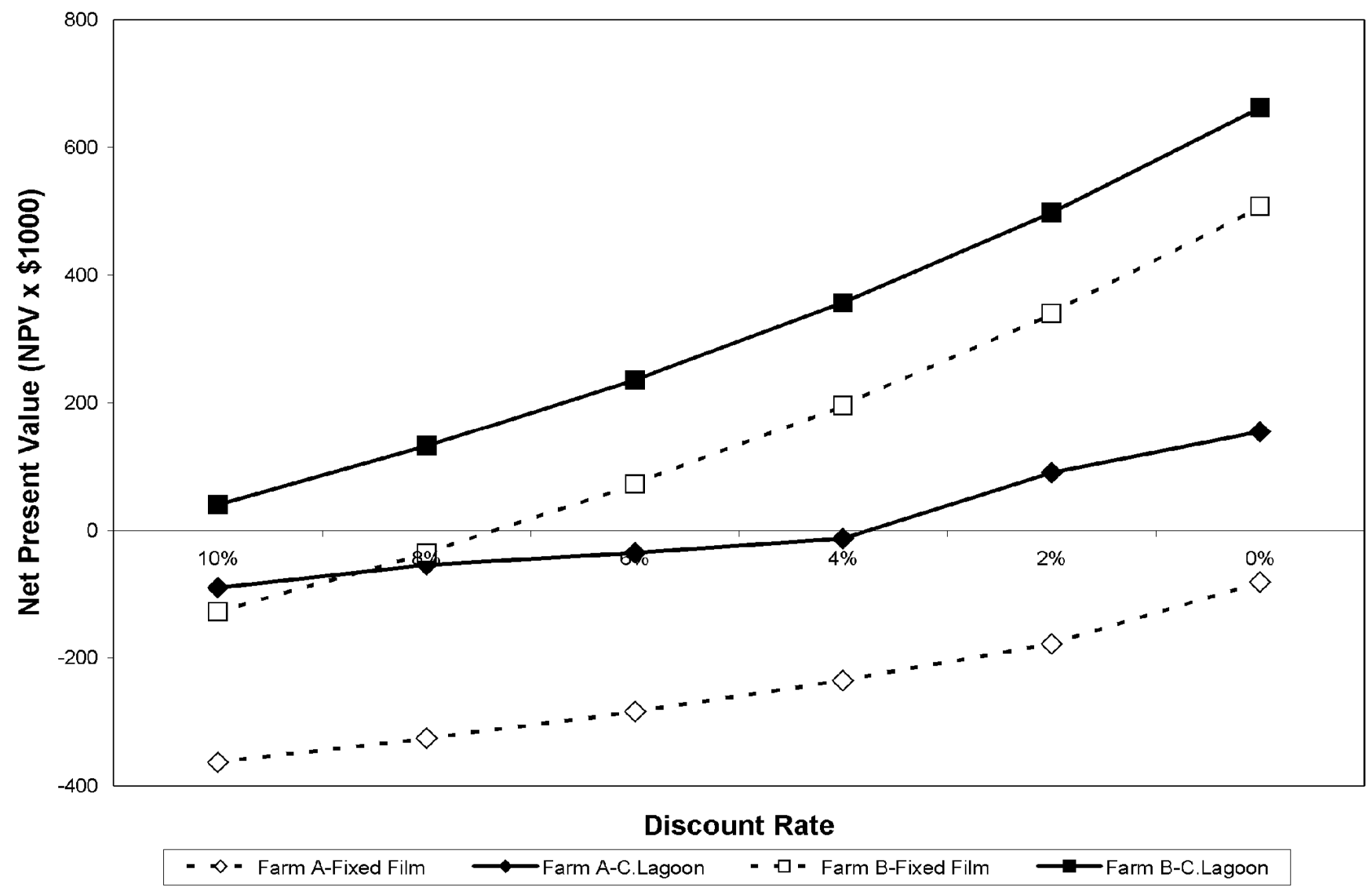

Figure 2. Effect of discount rate on the capital investment cost for electricity generation.

\section{Additional Discussion}

The assumptions used in this study resulted in a very conservative analysis. Water use per cow per day could, in practice, be lower than the 200 gallons that were assumed in this paper, and the efficiency of conversion of biogas to electricity can be higher than $25 \%$. These assumptions reduced the potential electrical output and resulted in the largest digester sizes and the lowest thermal efficiencies.

Some additional benefits of anaerobic digesters have not been considered in this paper, primarily because their values are currently not known or not quantifiable. For example, properly functioning anaerobic digesters can reduce odor and could also help meet air quality regulations. In this analysis, it was assumed that all process wastewater would be anaerobically digested, including wastewater that was recycled as flush water. If flush water was not digested prior to recycle, the size and cost of the digester could be reduced.
Current policies in Florida are not designed to stimulate small renewable energy production systems. Dairy farms can sell excess electrical energy to their local utility at an avoided cost ranging from $\$ 0.03$ to $\$ 0.04$ per $\mathrm{kWh}$. In this analysis, we assumed that the electricity used on the farm was valued at $\$ 0.10$ per $\mathrm{kWh}$, while excess electricity could be sold to the grid at $\$ 0.035$ per $\mathrm{kWh}$.

If a dairy farmer chooses to generate electricity from biogas and use it directly on the farm without selling it to an electric utility, the utility may institute a standby charge in case the farm needs to purchase that electricity from the utility when equipment fails or during maintenance. In some cases, these charges may offset the savings from using the electricity on the farm instead of selling it to the electric utility at relatively low wholesale rates.

The practice of trading carbon credits to offset the impact of greenhouse gas emissions on global warming presents the potential for an additional 
revenue stream for dairy farms installing anaerobic digesters. If an enterprise can document reductions in greenhouse gas emissions, it can trade these reductions. In this analysis, future revenue streams from carbon credit trading were not considered since the methodology and regulatory infrastructure for this practice are still in their infancies.

A $\$ 0.076$ per $\mathrm{kWh}$ federal tax credit is currently available for systems that generate energy via wind power. Legislation is currently being discussed that would extend a similar tax credit for anaerobic digesters. This study did not include this potential revenue source.

Some electric utilities charge customers a surcharge to purchase "green" power that has been generated from renewable sources. Examples of this practice include the Gainesville Regional Utilities program where customers elect to pay a $\$ 0.02$ per $\mathrm{kWh}$ premium to subsidize the generation of electricity from landfill gas. Such a program for manure-derived power would require negotiation between a dairy farm and its local utility. Thus, we have not included this potential revenue source in our calculations.

There are many other factors that affect the size, cost and design of anaerobic digestion systems on Florida dairy farms. For example, freestall bedding material must be considered in the design. If sand is used as bedding material, provisions must be made for removing it from the wastewater stream prior to the anaerobic digester. If organic bedding material, such as sawdust, compost, or wood shavings, is used in the barns, then this must also be considered in the design. There are also other issues with hurricane force winds and high groundwater table levels in Florida, particularly with the use of covered lagoons.Also, it should be noted that this analysis is based on a limited data set provided by only two consulting firms. A broader data set comprising data for more dairy farms and from a wider range of anaerobic digestion practitioners is needed to fully assess the economic feasibility of anaerobic digestion to produce electricity on Florida dairy farms. However, many indicators point towards an increasing cost of energy in the future, including electricity. Dairy farmers, therefore, should periodically assess the many options available for their waste management systems to determine the least cost or most profitable alternative for their particular situation.

\section{Conclusions and Recommendations}

1. Covered lagoon technology was economically more favorable over fixed-film digesters on all three dairy farms. A covered lagoon seemed to be an especially favorable choice at Farm B.

2. Results were very sensitive to cost-sharing opportunities. At $100 \%$ and $80 \%$ owner's share of capital cost, the projected net benefits were lower than what most dairy producers would expect from capital investments.

3. Results were also sensitive to the discount rate. At $8 \%$ and $10 \%$, NPV were predominantly negative. Low interest loans may be an additional incentive beyond cost-share opportunities to encourage implementation of these technologies.

4. At $100 \%$ owner's share of capital investment, $8 \%$ discount rate, and $\$ 0.10 / \mathrm{kWh}$ retail value of electricity, anaerobic digestion was feasible only for Farm B with a covered lagoon. However, at $\$ 0.12 / \mathrm{kWh}$, anaerobic digestion was also feasible for a fixed-film digester at Farm B and a covered lagoon at Farm A.

5. The results of this feasibility study are conservative. Given that wastewater volume is the primary determinant of digester sizing, further analysis is needed to develop costs based on more realistic conditions. Reducing the daily wastewater input to the digester units would have a major impact on digester volumes/size, and therefore capital cost, for the same biogas yield. The value of the environmental benefits from anaerobic digestion of dairy manure should also be considered in the investment decision. Although difficult to quantify in monetary terms, the benefits of odor reduction and compliance with air quality regulations may be substantial. 
Table 3. Effect of owner's share on the capital investment cost for electricity generation (NPV $\times \$ 1000$ ).

\begin{tabular}{ccccc}
\hline & \multicolumn{2}{c}{ Farm A } & \multicolumn{2}{c}{ Farm B } \\
\cline { 2 - 5 } Owner's Share & Fixed Film & Covered Lagoon & Fixed Film & Covered Lagoon \\
\cline { 2 - 5 } $100 \%$ & -326 & -54 & -36 & 132 \\
$80 \%$ & -195 & -19 & 140 & 277 \\
$60 \%$ & -64 & 92 & 314 & 422 \\
$40 \%$ & 52 & 168 & 490 & 568 \\
$20 \%$ & 169 & 239 & 665 & 714 \\
$0 \%$ & 286 & 312 & 840 & 858 \\
\hline
\end{tabular}

Table 4. Effect of discount rate on the capital investment cost for electricity generation (NPV $\times \$ 1000$ ).

\begin{tabular}{ccccc}
\hline & \multicolumn{2}{c}{ Farm A } & \multicolumn{2}{c}{ Farm B } \\
\cline { 2 - 5 } Discount Rate & Fixed Film & Covered Lagoon & Fixed Film & Covered Lagoon \\
\hline $10 \%$ & -363 & -90 & -128 & 40 \\
$8 \%$ & -326 & -54 & -36 & 132 \\
$6 \%$ & -284 & -35 & 72 & 236 \\
$4 \%$ & -235 & -13 & 196 & 357 \\
$2 \%$ & -178 & 90 & 340 & 498 \\
$0 \%$ & -81 & 154 & 508 & 662 \\
\hline
\end{tabular}

Table 5. Effect of retail value of electricity on the investment decision (NPV $\times \$ 1000)$.

\begin{tabular}{ccccc}
\hline & \multicolumn{2}{c}{ Farm A } & \multicolumn{2}{c}{ Farm B } \\
\cline { 2 - 5 } Retail Value $(\$ / \mathrm{kWh})$ & Fixed Film & Covered Lagoon & Fixed Film & Covered Lagoon \\
\hline 0.16 & 9 & 250 & 529 & 695 \\
0.14 & -74 & 167 & 341 & 507 \\
0.12 & -238 & 17 & 154 & 321 \\
0.10 & -326 & -54 & -36 & 132 \\
0.08 & -433 & -130 & -225 & -57 \\
0.06 & -543 & -218 & -434 & -246 \\
0.04 & -652 & -328 & -726 & -503 \\
\hline
\end{tabular}

\section{References}

AgSTAR Program, U.S. Environmental

Protection Agency. http://www.epa.gov/agstar/

Wilkie, A.C. (2005). Anaerobic Digestion of

Dairy Manure: Design and Process Considerations.

In: Dairy Manure Management: Treatment,

Handling, and Community Relations. NRAES-176,

p.301-312. Natural Resource, Agriculture, and

Engineering Service, Cornell University, Ithaca, NY,

2005. 


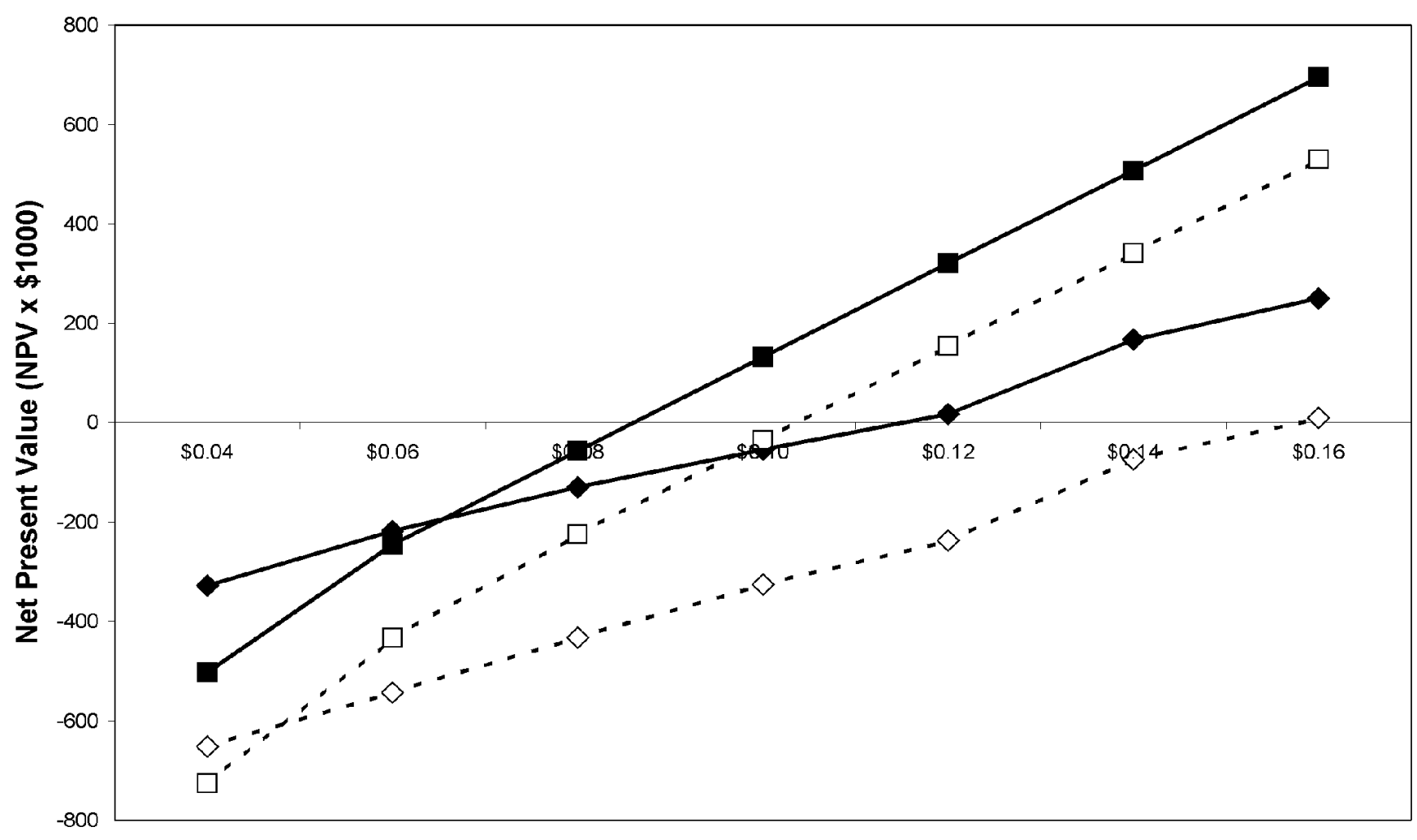

Retail Value per kWh

$$
\text { - } \diamond-\text { Farm A-Fixed Film —Farm A-C.Lagoon - - - Farm B-Fixed Film } \longrightarrow \text { Farm B-C.Lagoon }
$$

Figure 3. Effect of retail value of electricity on the investment decision. 